\title{
Aplikasi Diagnosa Granulomatous Dermatis Menggunakan Certainty Factor
}

\author{
Puji Sari Ramadhan \\ Program Studi Sistem Informasi, STMIK Triguna Dharma, Medan, Indonesia \\ Email: pujisariramadhan@gmail.com
}

\begin{abstract}
Abstrak
Granulomatous Dermatis merupakan penyakit yang berjenis peradangan pada lapisan dalam kulit yang menyebabkan kerusakan pada saraf, lapisan kulit dan anggota motorik tubuh. Penyakit ini bermula pada serangan kuman aerob berjenis mycobacterium leprae yang dapat menyebar dan menularkan infeksi dengan penularan melalui kontak dan udara, selain itu penyakit ini diperkirakan masuk ke Indonesia pada awal abad V. Pada saat sekarang ini pendiagnosaan dan penanganan Granulomatous Dermatis mengalami kesulitan, hal ini didasari dengan keterbatasannya informasi dan kurangnya pengetahuan para masyarakat tentang Granulomatous Dermatis sehingga nantinya akan dapat mengakibatkan terlambatnya atau ketidaksiapan penanganan pada pasien dengan kasus Granulomatous Dermatis. Atas dasar kejadian tersebut maka sangat perlu membangun sebuah sistem dengan mengakuisisi konsep keilmuan kecerdasan buatan yang mampu menghasilkan sebuah Sistem Pakar yang nantinya dapat dipergunakan dalam melakukan pendiagnosaan Granulomatous Dermatis dengan menerapkan analisa Certainty Factor. Dengan adanya aplikasi diagnosa ini nantinya dapat membantu masyarakat dan tenaga ahli medis dalam melakukan pendiagnosaan Granulomatous Dermatis sebagai sarana referensi dalam pengambilan kesimpulan diagnosa akhir.
\end{abstract}

Kata Kunci: Kecerdasan Buatan, Sistem Pakar, Certainty Factor, Aplikasi Diagnosa, Granulomatous Dermatis.

\section{Abstract}

Granulomatous dermatitis is a type of inflammatory disease in the inner layer of the skin that causes damage to the nerves, skin layers and motor members of the body. This disease originated in the attack of an aerobic type of mycobacterium leprae which can spread and transmit infection by contact and air, besides this disease is estimated to enter Indonesia in the early $\mathrm{V}$ century. At present the diagnosis and treatment of Granulomatous Dermatis is experiencing difficulties, this based on the limited information and lack of knowledge of the community about Granulomatous Dermatis so that later it will result in late or unpreparedness of treatment in patients with Granulomatous Dermatis cases. On the basis of these events, it is very necessary to build a system by acquiring scientific concepts of artificial intelligence that are capable of producing an Expert System which can later be used to diagnose Granulomatous Dermatis by applying the Certainty Factor analysis. With the application of this diagnosis later can help the community and medical experts in diagnosing Granulomatous Dermatis as a reference tool in concluding the final diagnosis.

Keywords: Artificial Intelligence, Expert Systems, Certainty Factor, Application of Diagnosis, Granulomatous Dermatis

\section{PENDAHULUAN}

Granulomatous Dermatis merupakan penyakit yang berjenis peradangan pada lapisan dalam kulit yang menyebabkan kerusakan pada saraf, lapisan kulit dan anggota motorik tubuh. Penyakit ini bermula pada serangan kuman aerob berjenis mycobacterium leprae yang dapat menyebar dan menularkan infeksi dengan penularan melalui kontak dan udara dan faktor genetika. Kuman yang mengindap di dalama tubuh memiliki jangka waktu inkubasi 2-5 tahun dan sumber utama penularan penyakit ini adalah antara sesama manusia. Menurut Organisasi Kesehatan Dunia pada tahun 1995 mengemukakan perkiraan bahwa Indonesia masuk ke dalam negara urutan ketiga terbesar atas kasus Granulomatous Dermatis dengan capaian kasus kurang lebih 3 juta jiwa cacat permanen.

Dengan melihat betapa besar potensi kemungkinan masyarakat terkena penyakit Granulomatous Dermatis serta belum meratanya sebaran informasi dan pengetahuan masyarakat terkait Granulomatous Dermatis sehingga akan menyebabkan terhambatnya penanganan pada masyarakat yang terdiagnosa penyakit tersebut, maka untuk itu perlu membangun sebuah aplikasi diagnosa yang dapat dipergunakan dalam melakukan pendeteksian Granulomatous Dermatis serta sebagai dapat dijadikan sebagai layanan pengambilan kesimpulan diagnosa bagi para ahli medis sebelum melakukan pemeriksaan lebih lanjut. Aplikasi diagnosa yang akan dibangun akan menggunakan salah satu konsep keilmuan kecerdasan buatan yaitu Sistem Pakar dengan penerapan metode Certainty Factor yang berfungsi untuk menghasilkan sebuah nilai kemungkinan atau probabilitas penyakit yang menyerang masyarakat dengan penelusuran gejala-gejala klinis yang dialami oleh masyarakat itu sendiri dengan terlebih dahulu menentukan nilai-nilai kepastian pada setiap gejala yang diperoleh dari pengetahuan ahli dibidang Granulomatous Dermatis.

Penerapan Sistem Pakar sendiri telah banyak dipergunakan dalam aktifitas sehari-hari untuk menemukan solusi atas permasalahan yang terjadi ditengah-tengah masyarakat dengan terlebih dahulu menanamkan pengetahuan para ahli ke dalam aplikasi atau sistem yang akan dipergunakan sebagai layanan kepakaran, hal ini terlihat dengan banyaknya penelitian yang berorientasi kepada konsep Sistem Pakar terutama dalam dunia medis diantaranya pada[1] digunakannya Sistem Pakar dalam mendiagnosa Rematik Polymiaglia, selain itu juga dalam [2] Sistem Pakar dipergunakan untuk menentukan jenis pengobatan terhadap penyakit pencernaan. Pada [3] Sistem Pakar diterapkan menjadi aplikasi untuk mendeteksi penyakit pada nanas, kemudian dalam [4] aplikasi 
Sistem Pakar diapat diterapkan dalam pendiagnosaan Dermatitis Imun, disamping itu pada[4] penerapan Sistem Pakar dalam melakukan diagnosa jenis penyakit gigi dan mulut. Kemudian dalam [5] dipergunakannya Sistem Pakar dalam menelusuri ciri-ciri ikan yang terindentifikasi zat formalin dan selanjutnya pada [5] disebutkan pengidentifikasian penyakit TB juga menerapkan teknologi Sistem Pakar dalam penelusuran kasus yang terjadi.

Dengan adanya aplikasi diagnosa ini dapat nantinya digunakan oleh masyarakat luas untuk mengetahui secara dini pendiagnosaan masyarakat yang kemungkinan menderita penyakit Granulomatous Dermatis sehingga dapat mengurangi angka penderita dan mempercepat penanganan medis secara dini serta dilakukannya pencegahan terdapat penyakit ini untuk dihentikannya penularan terhadap penyakit Granulomatous Dermatis.

\section{TEORITIS}

\subsection{Kecerdasan Buatan}

Pada penelitian sebelumnya[6] disebutkan bahwa Kecerdasan Buatan memiliki fungsi dalam membentuk sebuah aplikasi cerdas untuk dapat dijadikan sebagai solusi atau pemecahan permasalahan yang terjadi dengan terlebih dahulu menanamkan pengetahuan kedalam sistem tersebut, selain itu pada[7] mengemukakan bahwa AI memiliki prinsip dan konsep yang mampu mentransformasikan pengetahuan yang akan diterapkan ke dalam mesin yang dirancang berdasarkan algoritma dimasukkan. AI merupakan sebuah konsep filosofis yang mampu mengarahkan dan mengatur berbagai hal yang berkaitan dengan aktifitas hidup manusia[8], disamping itu terdapat pendapat pada[9] AI adalah bagian dari perkembangan cara berfikir manusia untuk dapat dijadikan sebagai pengambil keputusan yang terbaik.

\subsection{Sistem Pakar}

Pengenalan konsep Sistem Pakar dapat diketemukan pada[10] yang mengemukakan bahwa Sistem Pakar memiliki arti sebuah aplikasi yang terbentuk berdasarkan pengetahuan, pelacakan serta penerapan algoritma kerja sistem yang saling berhubungan untuk mencapai tujuan yang dapat digunakan dalam pemecahan permasalahan atau solusi dalam aktifitas yang sesuai dengan pengetahuan yang ditanamkan.

Kemudian dalam[11] dijelaskan bahwa Sistem Pakar memiliki fungsi untuk dapat mengadopsi suatu pengetahuan atau informasi kedalam sistem agar dapat menemukan solusi atas permasalahan yang ada dengan kualitas setara pakar, selain itu dalam [12] menyebutkan bahwa Expert System memiliki arti sebuah sistem pengetahuan yang digunakan untuk membantu menemukan solusi atas permasalahan yang ada pada kehidupan dunia nyata, sementara itu pada penelitian lainnya[13] mengemukakan bahwa ES mempunyai istilah sebagai suatu sistem berbasis pengetahuan yang digunakan dalam mencari tujuan yang telah ditanamkan informasi dengan kualitas pakar. Sistem pakar dirancang seperti manusia yang ahli untuk dapat membentuk pengetahuan dalam pemecahan permasalahan yang ada[14], kemudian Sistem Pakar akan menggunakan pengetahuan pakar dalam mengeksekusi permasalahan yang ada untuk menemukan hasil dari pelacakan yang dilakukan[15]. Sebuah kepakaran memiliki perananan penting dalam pembentukan sistem ES, hal ini dikarenakan sistem ini bergantung pada kemampuan kepakaran dalam mentransformasikan pengetahuan ke dalam sistem yang dibentuk[16].

Sebuah sistem pakar dapat dikatakan efektif jika sistem tersebut mengikuti perkembangan pengetahuan yang mudah dimodifikasi dan dapat diterima secara menyeluruh[17], kemampuan Sistem Pakar yang dapat bekerja dengan baik didorong dengan penggunaan inferensi yang mampu melakukan pelacakan fakta-fakta yang ada berdasarkan aturan yang telah ditetapkan serta pengumpulan pengetahuan agar dapat merumuskan hasil atau kesimpulan suatu kasus[18].

\subsection{Certainty Factor}

Dalam [19] menyebutkan bahwa Certainty Factor dikemukakan oleh Shortliffe beserta Buchanan yang dipublikasikan di tahun 1975 dalam mengadopsi suatu hal yang memiliki ketidakpastian dalam menemukan solusi atau tujuan. Certainty Factor ini dipergunakan ketika menemukan suatu kejadian atau permasalahan yang belum pasti jawaban.

Tabel 1. Nilai Kepastian

\begin{tabular}{cc}
\hline Uncertain Term & CF \\
\hline Definitely Not & -1.0 \\
\hline Almost Certainly Not & -0.8 \\
\hline Probably Not & -0.6 \\
\hline Maybe Not & -0.4 \\
\hline Unknown & -0.2 to 0.2 \\
\hline Maybe & 0.4 \\
\hline Probably & 0.6 \\
\hline Almost Certainly & 0.8 \\
\hline Definitely & 1.0
\end{tabular}


Berikut ini fungsi perhitungan Certainty Factor berjenis kombinasi 2 buah aturan dengan fakta evidence berbeda $\left(\mathrm{G}_{1}\right.$ dan $\left.\mathrm{G} 2\right)$, namun hipotesisnya sama :

$$
C F\left(c f_{1}, c f_{2}\right)=\left[\begin{array}{lc}
c f_{1}+c f_{2}\left(1-c f_{1}\right), & \text { jika } c f_{1} \text { dan } c f_{2}>0 \\
\frac{c f_{1}+c f_{2}}{1-\min \left[c f_{1}, c f_{2}\right]}, & \text { jika } c f_{1} \text { atau } c f_{2}<0 \\
c f_{1}+c f_{2}\left(1+c f_{1}\right), & \text { jika } c f_{1} \text { dan } c f_{2}<0
\end{array}\right]
$$

\subsection{Granulomatous Dermatis}

Granulomatous Dermatis merupakan penyakit yang berjenis peradangan pada lapisan dalam kulit yang menyebabkan kerusakan pada saraf, lapisan kulit dan anggota motorik tubuh. Penyakit ini bermula pada serangan kuman aerob berjenis mycobacterium leprae yang dapat menyebar dan menularkan infeksi dengan penularan melalui kontak dan udara dan faktor genetika. Kuman yang mengindap di dalama tubuh memiliki jangka waktu inkubasi 2-5 tahun dan sumber utama penularan penyakit ini adalah antara sesama manusia. Penyakit ini memiliki gejala-gejala klinis seperti panas, anoreksia, nausea disertai vomitus, cephalgia, iritasi, orchitis, pleuritis, nephrosia, nepritis, hepatosplessnomegali, neuritis, bercak gatal, dan lepuh tidak nyeri[20].

\section{ANALISA DAN PEMBAHASAN}

Penelitian ini akan menerapkan metode Reserch and Development yang memiliki fungsi untuk menghasilkan suatu sistem berbentuk suatu software aplikasi, yang akan diimplementasikan untuk melakukan pendiagnosaan Granulomatous Dermatis berdasarkan fakta yang terjadi pada pasien yang kemungkinan teridentifikasi Granulomatous Dermatis dengan Certainty Factor. Selain metode penelitian, terdapat kerangka kerja diantaranya pengumpulan knowladge base, pembentukan rule, melakukan proses perhitungan dengan Certainty Factor yang nanti akan diharapkan untuk dapat menghasilkan nilai persentase atau probabilitas Granulomatous Dermatis yang kemungkinan diderita oleh pasien atau masyarakat.

\subsection{Pengumpulan Knowladge Base}

Dalam pembangunan Sistem Pakar untuk melakukan pendeteksian Granulomatous Dermatis melalui penelusuran gejala klinis yang dialami oleh masyarakat yang kemungkinan teridentifikasi Granulomatous Dermatis, dibutuhkan penurunan pengetahuan serta informasi yang akan diakuisisi kedalam suatu aplikasi yang memiliki kemampuan untuk mencari solusi atas diagnosa yang akan dilakukan. Berikut ini adalah pengumpulan basis pengetahuan tentang Granulomatous Dermatis beserta gejela yang terjadi.

Tabel 2. Data Kepakaran

\begin{tabular}{cclc}
\hline No & Kode Gejala & \multicolumn{1}{c}{ Daftar Gejala } & Nilai Bobot \\
\hline 1 & G001 & Panas & 0,2 \\
\hline 2 & G002 & Anoreksia & 0,6 \\
\hline 3 & G003 & Nausea & 0,4 \\
\hline 4 & G004 & Cephalgia & 0,4 \\
\hline 5 & G005 & Iritasi & 0,2 \\
\hline 6 & G006 & Orchitis & 0,4 \\
\hline 7 & G007 & Pleuritis & 0,2 \\
\hline 8 & G008 & Nephrosia & 0,2 \\
\hline 9 & G009 & Nepritis & 0,4 \\
\hline 10 & G010 & Hepatosplessnomegali & 0,6 \\
\hline 11 & G011 & Neuritis & 0,4 \\
\hline 12 & G012 & Bercak Gatal & 0,2 \\
\hline 13 & G013 & Lepuh Tidak Nyeri & 0,4 \\
\hline
\end{tabular}

Dari data gejala yang telah dikemukakan, maka nantinya akan dibentuk rule atau aturan yang berfungsi untuk pedoman dalam melakukan pelacakan atau pencarian dalam melakukan pendeteksian Granulomatous Dermatis.

\subsection{Pembentukan Rule}

Pada tahapan ini akan dilakukan pembentukan aturan yang berkaitan pengetahuan tentang Granulomatous Dermatis hal ini dapat dilakukan setelah memperoleh informasi dari basis pengetahuan yang terdiri dari gejala- 
gejala serta nilai probabilitas setiap gejala. Berdasarkan hasil dari basis pengetahuan yang diperoleh, maka terbentukanlah sebuah rule, mengingat pada kasus ini hanya terdapat satu penyakit saja maka dalam penelitian ini akan menghasilkan satu rule atau hipotesa juga.

Rule 1 : IF Panas=Yes, AND Anoreksia=Yes, AND Nausea=Yes, AND Cephalgia=Yes, AND Iritasi=Yes, AND Orchitis=Yes, AND Pleuritis=Yes, AND Nephrosia=Yes, AND Nepritis=Yes, AND Hepatosplessnomegali=Yes, AND Neuritis=Yes, AND Bercak gatal=Yes, AND Lepuh tidak nyeri $=$ Yes THEN Penyakit $=$ Granulomatous Dermatis

Setelah melakukan proses pembentukan rule, maka tahapan selanjutnya adalah melakukan proses perhitungan dengan menggunakan Certainty Factor untuk menghasilkan nilai probabilitas atau persentase terhadap gejala-gejala yang dialami oleh pasien.

\subsection{Penerapan Certainty Factor}

Dari pembentukan rule yang telah dibuat dan penetapan bobot gejala yang telah dilakukan maka selanjutnya pada tahapan ini akan dilakukan perhitungan dengan menggunakan Certainty Factor, dengan menggunakan contoh kasus sebagai berikut :

Tabel 3. Data Kasus

\begin{tabular}{cccc}
\hline No & \multicolumn{2}{c}{ Gejala Dialami } & Diagnosa \\
\hline 1 & Panas $(G 01)$, & Anoreksia(G02), & $? ? ?$ \\
\hline
\end{tabular}

Penyelesaian :

Langkah Ke-1 : Menghitung nilai bobot G01 dengan G02

$\mathrm{CF}($ Panas, Anoreksia $)=0.2+0.6(1-0.2)=0.68(\mathrm{CF}$ Kombinasi $)$

Langkah Ke-2 : Menghitung nilai kombinasi (G01 dan G02) dengan G03

$\mathrm{CF}($ Kombinasi, Nausea $)=0.68+0.4(1-0.68)=0.80($ Hasil $\mathrm{CF})$

Berdasarkan proses perhitungan yang telah dilakukan dengan Certainty Factor maka hasil perhitungan untuk penyakit Granulomatous Dermatis adalah 0.80 atau $80 \%$.

\section{IMPLEMENTASI}

Pengimplementasian Sistem Pakar ini dengan menerapkan dan membangun suatu layanan diagnosa yang dapat dipergunakan untuk mengatur dan memformulasikan data dan informasi yang berkaitan tentang Granulomatous Dermatis.Berikut adalah interface halaman dari layanan aplikasi yang telah dibangun dalam melakukan pendeteksian Granulomatous Dermatis dengan menerapkan Certainty Factor. Pengujian sistem ini meliputi akses halaman utama kemudian melakukan pengisian data pasien serta yang terakhir adalah melakukan pemilihan gejala-gejala yan diderita sehingga nantinya akan memunculkan nilai kepastian atau persentase kemungkinan dari penyakit Granulomatous Dermatis yang telah dihitung melalui penerapan analisis Certainty Factor. Berikut ini langkah-langkah pengujian sistem yang telah dihasilkan :

\section{Masuk Halaman Utama}

Dalam melakukan konsultasi pada layanan diagnosa, maka perlu terlebih dahulu masuk ke halaman utama, halaman ini berisi banyak menu layanan yang bisa digunakan oleh masyarakat tentunya yang berkaitan dengan Granulomatous Dermatis. Berikut interface dari halaman utama :

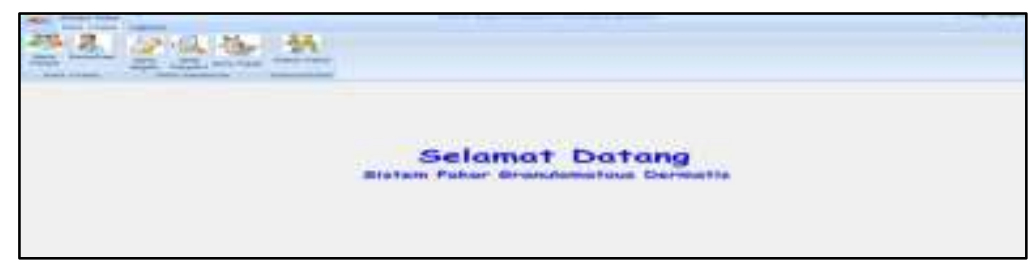

Gambar 1. Halaman Utama

\section{Mengentri Data Pasien}

Layanan diagnosa akan dapat berfungsi atau aktif, jika data pasien telah terlebih dahulu sudah terisi dengan lengkap, maka tentunya sebelum melakukan pendiagnosaan pasien atau masyarakat hendaknya melakukan pengisian data-data pribadi yang berkaitan dengan pasien yang akan didiagnosa. Berikut tampilan data pasien :

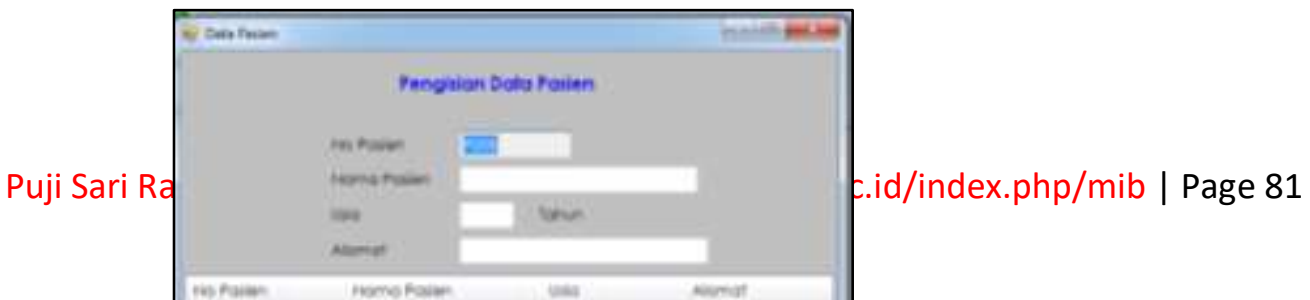




\section{Gambar 2. Data Pasien}

Pada form data pasien terdapat pengolahan modifikasi data, diantaranya adalah penyimpanan data diri pasien, kemudian fasilitas perubahan data, serta layanan penghapusan data diri pasien jika sewaktu-waktu terdapat perubahan pada identitas diri pasien atau masyarakat.

\section{Melakukan Pendiagnosaan}

Pada halaman diagnosa ini berisikan tentang data gejala yang dibentuk berdasarkan basis pengetahuan yang ada, selain itu terdapat nomor dan nama pasien yang akan didiagnosa, dalam pendiagnosaan Granulomatous Dermatis juga akan memunculkan nilai kepakaran atau kepastian dari persentase perhitungan yang telah dilakukan dengan menggunakan Certainty Factor, selain itu proses pendiagnosaan ini dapat dilakukan pencetakan hasil yang berguna sebagai bahan referensi dalam pengambilan keputusan diagnosa tentang Granulomatous Dermatis, berikut adalah tampilan dari halaman layanan konsultasi diagnosa Granulomatous Dermatis :

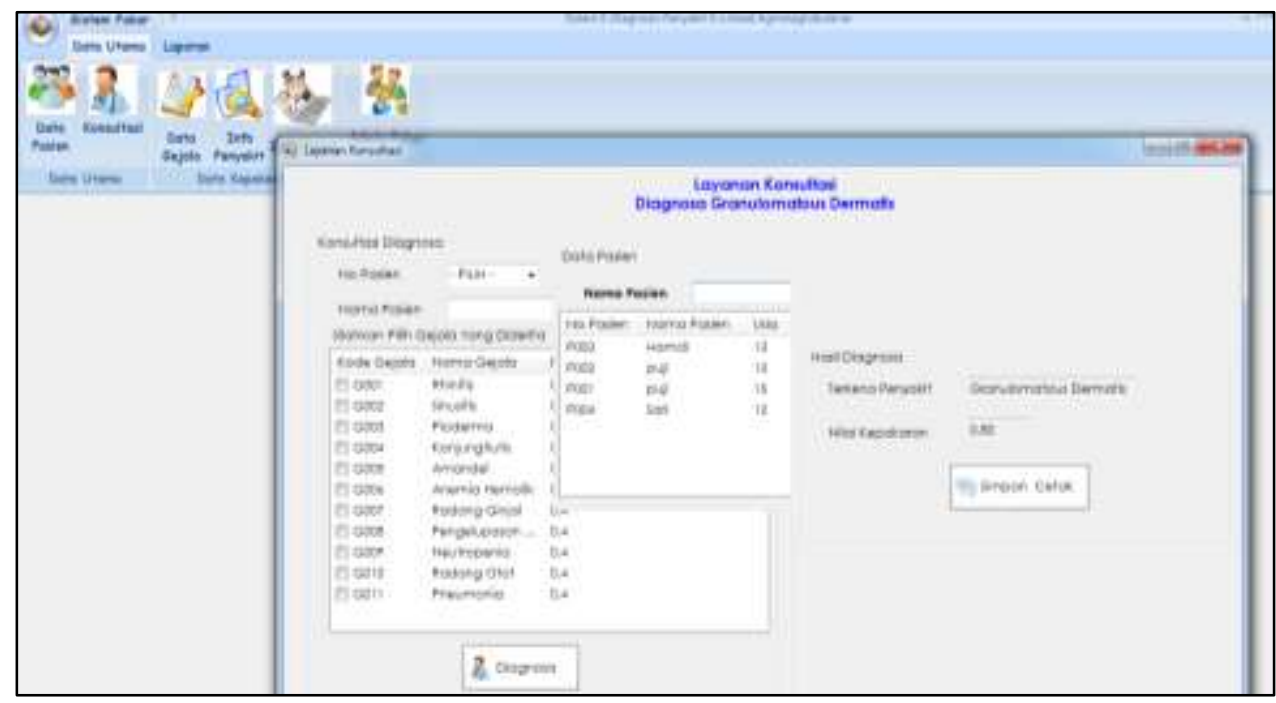

Gambar 3. Layanan Konsultasi Diagnosa

Penggunaan layanan konsultasi diawali dengan memilih nomor serta nama pasien yang akan dilakukan penidiagnosaan, setelah itu mencentang gejala-gejala yang diderita pasien, kemudian gejala-gejala yang telah terpilih selanjutnya akan diproses setelah mengklik tombol diagnosa pada tampilan layar, nantinya sistem akan menampilkan hasil pendiagnosaan Granulomatous Dermatis yang menyesuaikan dengan gejala-gejala yang dipilih dari basis pengetahuan dan rule yang dibentuk beserta nilai probabilitas atau kepastian yang diproses dan dihitung dengan menggunakan konsep dan cara kerja metode Certainty Factor sehingga akan menghasilkan solusi atas diagnosa yang dilakukan.

\section{KESIMPULAN}

Berdasarkan penelitian yang dilakukan tentang pembangunan sistem layanan konsultasi diagnosa Granulomatous Dermatis dengan penggunaan metode analisis Certainty Factor, maka dapat diperoleh kesimpulan sebagai berikut

1. Pembangunan Sistem Pakar untuk pendiagnosaan Granulomatous Dermatis ini memiliki tahapan yang harus dilalui, meliputi : pengumpulan data pengetahuan yang berkaitan dengan data gejala, penyakit, kepastian 
penyakit Granulomatous Dermatis yang akan diolah menjadi aturan atau rule dan dilakukan perhitungan menggunakan Certainty Factor dengan cara memindahkan keilmuan serta pengetahuan ke dalam sistem cerdas berbasis komputer.

2. Sistem layanan diagnosa ini dibangun dengan menerapkan konsep Certainty Factor dalam proses perhitungan terhadap Granulomatous Dermatis yang pada umumnya menyerang dan menular pada masyarakat telah sesuai dengan langkah-langkah penerapan Certainty Factor, sehingga sistem ini dapat dipergunkan sebagai aplikasi pendiagnosaan Granulomatous Dermatis dan memiliki fungsi untuk dijadikan pengambilan diagnosa awal oleh para petugas medis

\section{REFERENCES}

[1] M. El Agha, A. Jarghon, and S. S. A. Naser, "Polymyalgia Rheumatic Expert System," no. August, 2017.

[2] Ashari, "Penerapan Sistem Pakar Untuk Mendiagnosa Penyakit Pecernaan Dengan Pengobatan Alami," no. November, pp. 1-9, 2016.

[3] D. Gede and H. Divayana, "Application of Pineapple Diseases Expert System with FC-FL Method at Badung Regency Agriculture Department," vol. 4, no. 8, pp. 293-298, 2014.

[4] P. S. Ramadhan, "SISTEM PAKAR PENDIAGNOSAAN DERMATITIS IMUN MENGGUNAKAN TEOREMA BAYES," InfoTekJar(Jurnanl Nas. Inform. dan Teknol. Jaringan), vol. 3, no. 73, pp. 43-48, 2018

[5] F. M. Hadini, "Detection System Milkfish Formalin Android-Based Method Based on Image Eye Using Naive Bayes Classifier," vol. 9, no. 1, pp. 2-5, 2017.

[6] Mohamad Hadi, M. Misdram, and R. F. A, "Perancangan Sistem Pakar Diagnosa Penyakit Ayam Dengan Metode Forward Chaining," JImp, vol. 2, no. no bagian volume, pp. 111-139, 2016.

[7] A. K. Verawaty, Mesran, Suginam, “Jambu Biji Menggunakan Metode Bayes,” vol. 2, no. 1, pp. 78-81, 2017.

[8] A. Al-Ajlan, "The Comparison between Forward and Backward Chaining," Int. J. Mach. Learn. Comput., vol. 5, no. 2, pp. 106-113, 2015.

[9] S. Qwaider and S. S. A. Naser, "Expert System for Diagnosing Ankle Diseases," no. August, 2017.

[10] P. S. Ramadhan, "Sistem Pakar Pendeteksian Varicella Simplex Dengan Menggunakan Teorema Bayes," vol. 5, no. 5, pp. 454-459, 2018.

[11] S. A. Putri and E. P. Saputra, "Perancangan Aplikasi Sistem Pakar Diagnosa Awal Kanker Reproduksi Wanita Dengan Metode Certainty Factor," vol. 2, no. 3, pp. 63-68, 2018.

[12] F. Masya, H. Prastiawan, and S. Mubaroq, "Application Design to Diagnosis of Bone Fracture ( Traditional) using Forward Chaining Methods,” Int. Res. J. Comput. Sci., vol. 3, no. 09, pp. 23-30, 2016.

[13] Minarn, I. Warman, and W. Handayani, "Case-Based Reasoning (Cbr) Pada Sistem Pakar Identifikasi Hama Dan Penyakit Tanaman Singkong Dalam Usaha Meningkatkan Produktivitas Tanaman Pangan,” J. TEKNOIF, vol. 5, no. 1, pp. 41-47, 2017.

[14] J. Divya and K. Sreekumar, “A Survey on Expert System in Agriculture," Int. J. Comput. Sci. Inf. Technol., vol. 5, no. 6, pp. 78617864, 2014

[15] B. Sinaga, P. M. Hasugian, and A. M. Manurung, "Sistem Pakar Mendiagnosa Kerusakansmartphone,” vol. 3, no. 1, 2018.

[16] A. Suyatno and D. M. Khairina, "PENDETEKSI GANGGUAN JARINGAN LOKAL MENGGUNAKAN METODE CERTAINTY FACTOR," vol. 13, no. 2, pp. 60-64, 2018.

[17] S. Nurajizah and M. Saputra, "Sistem Pakar Berbasis Android Untuk Diagnosa Penyakit Kulit Kucing Dengan Metode Forward Chaining," J. Pilar Nusa Mandiri, vol. 14, no. 1, pp. 7-14, 2018.

[18] P. S. Ramadhan and Fatimah, "Sistem E-Healthcare Untuk Mendiagnosa Penyakit Inflamasi Dermatitis Imun Anak Dengan Menggunakan Metode Certainty Factor," vol. 1, no. 1, pp. 251-256, 2018.

[19] P. S. Ramadhan and U. Fatimah, "Analisis Perbandingan Metode ( Certainty Factor, Dempster Shafer dan Teorema Bayes ) untuk Mendiagnosa Penyakit Inflamasi Dermatitis Imun pada Anak," Saintikom, vol. 17, no. 2, pp. 151-157, 2018.

[20] A. Maharani, Penyakit Kulit, 1st ed. Yogyakarta: Pustaka Baru Press, 2015. 